\title{
GENETIC VARIABILITY AND CHARACTER ASSOCIATION IN DOLICHOS BEAN
}

\author{
V. Magalingam, Mohammed Yassin and S. Ramesh Kumar ${ }^{{ }^{*}}$ \\ Department of Horticulture, Pandit Jawaharlal Nehru College of Agriculture and Research Institute, \\ TNAU, Karaikal-609 603, Tamil Nadu, India
}

\begin{abstract}
Field bean (Dolichos lablab L.) is an important vegetable crop throughout India due to its local acceptability by the people. It has wide genetic variability for various traits like plant habit, branching habit, stem pigmentation, pod colour and pod characters etc. In the past, very little attention was given by the scientists on systematic crop improvement in Dolichos bean. The present investigation was laid out in a simple randomized complete block design with three replications during rabi 2011-2012 to study the variability present in 23 genotypes of dolichos bean. Analysis of variance revealed that there were significant differences among the genotypes for all the characters studied. The difference between PCV and GCV was narrow for all characters except percentage of pod set. Hence, these characters were less influenced by environment. High GCV and heritability estimates were associated with greater genetic advance for the nine traits viz., percentage of pod set, number pods per cluster, number pods per plant, green pod length, green pod width, individual green pod weight, pod yield, crude protein and crude fibre indicating that these characters had additive gene effect and were more reliable for effective selection in the improvement of dolichos bean. It is inferred from correlation and path analysis that the individual green pod weight, percentage of pod set, number of flowers per cluster and number of pods per plant exhibited significant positive correlation and direct positive effect on yield. Hence, these traits may be used as selection indices for yield improvement of dolichos bean.
\end{abstract}

Key words: multivariate analysis, pod characters, selection, sem

\section{INTRODUCTION}

Dolichos bean [Lablab prupureus (L.) Sweet] is an important leguminous vegetable of India and is mainly grown for its tender pods which are cooked and

\footnotetext{
${ }^{*}$ Corresponding author e-mail: rameshamar06@gmail.com

${ }^{1}$ Department of Horticulture, Vanavarayar Institute of Agriculture, Manakkadavu, Pollachi-642 103, TNAU, Tamil Nadu, India
}

Received: 07.08.2013 
consumed as vegetable. It is also called as sem, hyacinth bean, field bean and avarai. Being leguminous vegetable, the immature green pods of dolichos bean is a good source of protein, minerals and vitamins (Basu et al., 1999). Based on historical evidences, India is considered as origin and primary centre of diversity for dolichos bean. It is one of the most ancient crop among the cultivated plants grown as either pure or mixed with other crops, such as finger millet, groundnut, castor, corn or sorghum. It is also grown in homestead. It is a multipurpose crop grown as pulse, vegetable and forage. Field bean is a drought tolerant crop grown in dry lands with limited rainfall. The crop prefers relatively cool season when sowing done in JulyAugust. It starts fruiting in winter and continues indeterminately in spring (Savitha, 2008). Despite having many good attributes, the crop has remained unexploited owing to low productivity, long duration, photosensitivity and indeterminate growth habit. The consumer preference also varies with pod size, shape, colour and aroma (Sogadu). The efforts of improving the crop by utilizing indigenous and exotic germplasm have been useful in breaking the yield barriers resulting in compact plant type, reduced duration and photo-insensitive types. Hence, comprehensive germplasm collection and evaluation, identification of suitable genotypes for pure crop and investigation of its value as an intercrop with other food and forage crops are essential. The crop is mainly grown for its green pods, while the dry seeds are used in various vegetable preparations. It is one of the major sources of protein in South Indian dietary. A wide range of variations exist for the plant and pod characters amongst the accessions grown all over the country. The success of any breeding programme in general and improvement of specific trait through selection in particular, totally depends upon the genetic variability present in the available germplasm of a particular crop (Parmar et al. 2013). Since, many of the plant characters are governed by polygenes and greatly influenced by environmental conditions; the progress of breeding is, however, conditioned by the magnitude, nature and interrelationship of genotypic and non-genotypic variation. Among the quantitative characters, yield is a complex character, which is dependent on a number of yield contributing characters (Savitha, 2008). The knowledge of the association of yield components and their relative contribution shown by path analysis has practical significance in selection. The study of the association between pairs of characters and yield provide basis for further breeding programme. With a view to measuring the variability among the 23 genotypes for flower and pod characters, getting information on the associations of flower and pod characters with pod yield and assessing the degree of divergence among the genotypes as well as assessing the relative contribution of different components, the present study was undertaken with the following objectives.(i) to study the nature and magnitude of variability in dolichos genotypes; (ii) to understand the degree and direction of association between yield and its components and among themselves; (iii) to assess the direct and indirect effects of traits on yield. 


\section{MATERIALS AND METHODS}

The present evaluation of Dolichos bean genotypes suitable for coastal region of Karaikal in U.T. of Puducherry was conducted in the college orchard, Department of Horticulture, Pandit Jawaharlal Nehru College of Agriculture and Research Institute, Karaikal during rabi season 2012. The experimental material consisted of 23 genotypes of dolichos bean collected from NBPGR (National Bureau of Plant Genetic Resources), New Delhi; TNAU (Tamil Nadu Agricultural University); IIHR (Indian Institute of Horticultural Research), and local varieties of Tamil Nadu and Puducherry. The details of the accessions are given in table 1. The experiment was laid out in the Eastern block of PAJANCOA \& RI, Karaikal during NovemeberMarch, 2012. The experimental site is situated between $10^{\circ} 49^{\prime}$ and $11^{\circ} 01^{\prime} \mathrm{N}$ Latitude and $78^{\circ} 43^{\prime}$ and $79^{\circ} 52^{\prime}$ E Longitude with an altitude of four meters from the sea level. The soil type of the experimental plot was clay loam with medium fertility. Karaikal has tropical climate and receives an average annual rainfall of $915.5 \mathrm{~mm}$ in 44 rainy days. The farm pond water was used for irrigating the experimental field. The field experiment was laid out in a randomized block design with three replications during rabi season 2012. The plants were spaced $60 \mathrm{~cm}$ between row and $30 \mathrm{~cm}$ between plants in a row. Recommended horticultural practices and plant protection measures were followed uniformly. The observations were recorded from ten randomly selected plants per replication on each genotype for 15 characters viz., plant height, number of branches per plant, days to 50 percent flowering, number of flowers per cluster, number of clusters per plant, percentage of pod set, days to maturity, number of pods per cluster, number of pods per plant, green pod length, green pod width, individual green pod weight, pod yield per plant, crude protein content and crude fibre content. Crude protein content of the pods was estimated by Bremner (1965). Crude fibre content of pods was estimated by the method of Sadasivam and Manickam (1996). The mean values were subjected to statistical analysis. Correlation, variability and path coefficient analysis were carried out by using GENRES software.

\section{RESULTS AND DISCUSSION}

\section{(I) Variability studies}

Variability of a character is measured by range and genotypic coefficient of variation (Rahman et al., 2002). The range in the mean values reflects the extent of phenotypic variability present in the entries. In this way, the values include genotypic, environmental and genotype $\mathrm{x}$ environmental components. So, the estimation of genetic (heritable) and environmental (non-heritable) components of the total variability are required as these help us in the choice of suitable breeding programme. In the present investigation the difference between PCV and GCV was compared for different traits and it was found to be relatively narrow for almost all the characters expect for percentage of pod set, indicating the presence of low degree 
of environmental influence on these characters. Regarding the percentage of pod set, the difference between PCV and GCV was moderately higher which indicates that this trait is much influenced by environment. Since GCV represents the heritable components of total variation, it would be more appropriate to use this parameter for comparing variability of different characters among genotypes in dolichos bean.

In the present investigation, high GCV was recorded for percentage of pod set, number of pods per cluster, number of pods per plant, green pod length, green pod width, individual green pod weight, green pod crude protein, green pod crude fiber and pod yield (Table 2). This indicated the maximum variability existing in the genotypes for these characters and offers good scope for improvement of these traits by simple selection. Similar findings were reported by Golani et al. (2007) and Mohan et al. (2009) in dolichos bean. Moderate GCV was observed for plant height, number of branches per plant, number of flower per cluster, number of cluster per plant and days to maturity, whereas lowest GCV was observed for days to 50 percent flowering. These lowest and moderate GCV estimates for these traits revealed that the extent of response of these traits for selection would be lesser than that of the other traits.

High genotypic coefficient of variation (GCV) alone is not sufficient for determination of the heritable variation, as it simply measures the extent of genetic variability present for a character. Hence, GCV together with heritability estimates would give the best picture of the advance to be expected by selection. In the present investigation, high heritability estimates were observed for all the characters studied (Table 2). High heritability ranged from 74.270 for number of branches per plant to 99.730 for green pod crude fiber. High heritability values obtained for most of the traits suggested that this might generally be governed by additive gene action and hence the phenotype could provide fairly reliable measure of genotypic effect. Hence, selection could be exercised on the phenotypic performance. Higher estimates of genetic advance $(\geq 40 \%)$ as percent of mean were observed for 9 traits out of 15 (Table 2). Moderate genetic advance as percentage mean was observed for the rests. Heritability estimates in broad sense alone do not serve as the true indicator of genetic potentiality of the genotypes since the scope is restricted by their interaction with environment. High heritability coupled with high genetic advance as percent of mean was observed for 9 traits viz., percent of pod set, number pods per cluster, number pods per plant, green pod length, green pod width, individual green pod weight, green pod crude protein, green pod crude fiber and pod yield per plant. These traits have also high GCV. This indicates the presence of additive genes and consequently there is an ample scope of improving these characters by simple selection. High heritability coupled with moderate genetic advance as percent mean was observed for plant height, number of flower per cluster, number of cluster per plant, days to maturity, number of branches per plant and days to 50 percentage of flowering, indicate the presence of dominance and epistatic gene action effects in controlling these characters. Similar trends were observed by Bendale et al. (2004) in lablab bean. 


\section{(ii) Correlation studies}

Although variability estimates provide information on the extent of improvement through selection but they do not throw much light on the extent and nature of relationship between the characters which could be utilized for selection following hybridization. The correlation studies revealed higher estimates of genotypic correlation coefficients than their corresponding phenotypic correlation coefficients, suggesting a strong inherent relationship between different traits and that the environmental factors had not played much role in expression of the phenotypic.

\section{Genotypic correlation coefficient for yield and quality traits}

The genotypic correlation of pod yield with yield components revealed that the pod yield per plant was positively and significantly associated with green pod width, number of flowers per cluster, pod length and individual green pod weight (Table 3). It implied that these characters strongly influenced the pod yield per plant. Percent of pod set and number of pods per plant exhibited non- significant positive correlation with pod yield. A similar trend was reported by Ali et al. (2005) and Roy et al. (2006).

Negative correlation was observed for days to 50 percent flowering and days to maturity. This association indicated that these characters shall be taken into consideration for improvement of dolichos bean crop for earliness. Significant negative correlation of other characters with green pod yield implied that there was a little scope for consideration of these characters for the improvement of green pod yield in dolichos bean. Based on the above discussion, it could be inferred that the most important pod characters such as green pod length, number of flowers per cluster, green pod width and individual green pod weight may be considered for intentional selection in simultaneous improvement on pod yield per plant. In addition to these characters, percentage of pod set and number of pods per plant can also be taken into consideration for improvement on pod yield. The parameters such as days to 50 percent flowering and days to maturity were negatively correlated with yield and hence these characters could be considered for earliness.

In the inter correlation among the components characters, plant height was significantly and positively correlated with days to 50 percent flowering and days to maturity. This result indicated that increase in plant height caused late flowering and consequently the maturity was also delayed. The percentage of pod set was positively correlated with number of pods per cluster and number of pods per plant. These results clearly indicated that the percentage of pod set is one most important trait for increasing the production of more number of pods per plant. However, increased percentage of pod set and increased number of pods per cluster as well as number of pods per plant were negatively correlated with green pod length, green pod width and individual green pod weight. The length of pod had positive association with green pod width and individual green pod weight. Therefore, knowledge on the inter correlation association of component traits with pod yield per plant will help making selection more precise and accurate. 


\section{Phenotypic correlation coefficient for yield and quality traits}

In the present investigation the phenotypic correlation coefficients also showed similar trend as exhibited by genotypic correlation wherein the green pod width had strong positive correlation with yield. In addition, the green pod width, green pod length, number of flowers per cluster, number of pods per plant and percent pod set had direct positive effect on yield (Table 3). It indicated that these characters can be considered for selection in the improvement of pod yield per plant. Similarly, the inter correlation among components traits, the flower characters as well as pod traits were inter associated among themselves.

From the above discussion it may be concluded that the most important traits viz., green pod length, green pod width, number of flowers per cluster and individual green pod weight were found to be positively and significantly correlated both at genotypic and phenotypic levels, indicating that these traits may be considered as very important in selection and any improvement in these four characters would bring about an enhancement in yield. For earliness, parameters such as days to 50 percent flowering and days to maturity may be taken into consideration. It is also suggested that hybridization of genotypes possessing combination of such characters will be useful for obtaining desirable segregants. Similar reports were reported by Sonali et al. (2009) in pea.

\section{(iii) Path analysis}

Selection of superior genotypes based on yield as such may not be effective for the enhancement of yield and hence selection should be made for component traits as well. Association of yield components thus assumes a unique prominence as the basis for selecting desirable genotypes with high yield potential. In addition, knowledge on presence of association among component characters reveals that some of them may serve as indicators of yield. In the present study, the path analysis reveals that individual green pod weight exhibited very high direct positive effect (3.72) on pod yield per plant. In addition, percent pod set, number of clusters per plant, pods per plant and flowers per cluster and days to 50 percent flowering also showed very high direct positive effect on pod yield (Table 4). This indicated that these characters played an important role in increasing the pod yield. Therefore, the direct selection of these characters may about bring an overall improvement in pod yield. These findings were in agreement with the results reported Desai et al. (2003) in dolichos bean, where the number of branches per plant, green pod crude protein showed high and direct positive effects respectively on pod yield.

The days to maturity, pod length, plant height, green pod width and number of pods per cluster had negatively direct effect on yield per plant. The residual effect determines how best the causal factor accounts for the variability of the dependent factor that is yield per plant in this study. In the present investigation the residual effect of path coefficient analysis was 0.1519 , which clearly indicated that the 15 characters taken for this investigation were sufficient for genetic analysis in dolichos 
bean. Only $15 \%$ of the variability was controlled by other traits besides these 15 characters. Based on the above results the traits such as, individual green pod weight and number flowers per cluster, number of clusters per plant, percentage of pod set and number of pods per plant were important yield contributing traits which were positive and significantly correlated with pod yield and also showed high direct effect on pod yield. For earliness, days to 50 percent flowering had to be considered. Therefore, these traits shall be used as selection criteria for the improvement of yield directly in dolichos bean.

\section{REFERENCE}

Ali, F., Sikdar B., Roy, A.K. and Joarder, O.I. 2005. Correlation and genetic variation of twenty different genotypes of lablab bean, Lablab purpureus (L.) Sweet. Bangladesh Journal of Botany, 34(2): 125-128

Basu, A.K., Pal, D, Sasmala, S. C. and Samanta, S.K. 1999. Genetic analysis for embryo weight, cotyledon weight and seed protein in lablab bean. Vegetable Science, 26:37-40

Bendale, V.W., Topare, S. S. Bhave, S.G. Mehta, J. K. and Madav, R.R. 2004. Genetic analysis of yield and yield components in lablab bean (Lablab purpureus (L.) Sweet). Orissa Journal of Horticulture, 32: 99-101

Bremner, J.M., 1965. In: Methods of soil analysis, Part 2, Black, C.A.(Ed.), American Society of Agronomy 9: Inc., publishers.USA

Desai, S., Bendale B., Bhave, V.W., Madav, S. G. and Mehta, J.L. 2003. Heterosis for growth and developmental characters in labalab bean (Lablab purpureus L. Sweet). Research on Crops 4 (3): 366-372. College of Agriculture, Dapoli. Maharashtra, India

Golani, I.J., Mehta, D.R. and Naliyadhara, M.V. (2007). Genetic variability, correlation and path analysis for green pod yield and its characters in hyacinth bean. The Orissa Journal of Horticulture, 35(1): 71-75

Mohan, N., Aghora, T.S. and Devaraju. (2009). Evaluation of dolichos (Lablab purpureus L.) germplasm for pod yield and pod related traits. Journal of Horticultural Sciences,4(1): 50-53

Parmar1, M., Singh, A. P., Dhillon1, N. P. S. and Jamwal, M. (2013). Genetic variability of morphological and yield traits in Dolichos bean (Lablab purpureus L.). African Journal of Agricultural Research, 8(12):1022-1027

Rahman, M.A., Hossain, M.D., Islam, M.S., Biswas, D.K. and Ahiduzzaman, M. (2002). Genetic variability, heritability and path analysis in snake gourd (Trichosanthus anguina L.). Pakistan Journal of Biological Sciences, 5(3): 284-286

Roy, S.K., Karim, M.A., Islam, A.K.M.A., Bari, M.N., Mian, M.A.K. and Hidak. T. 2006. Relationship between yield and its component characters of bush bean (Phaseolus vulgaris L.). South Pacific studies, 27(1): 13-23

Sadasivam, S. and Manickam, A. 1996. Biochemical methods. New age international (P) limited, Publishers, New Delhi. pp. 20-21

Savitha B.N.2008. Characterization of avare (Lablab purpureus (L.) Sweet) local collections for genetic variability. M. Sc. (Agri.) Thesis, Uni. Agri. Sci., Bangalore (India)

Sonali. G., Nirmala, C. and Saroj, D. 2009. Genetic variability, correlation and path analysis studies in pea (Pisum Sativum L.). Crop Research, 38(1, 2 and 3): 179-183 
Table 1: Sources of Dolichos bean

\begin{tabular}{|c|c|c|c|}
\hline $\begin{array}{l}\text { S. } \\
\text { No. }\end{array}$ & $\begin{array}{l}\text { Genotype designation } \\
\text { used in text and tables }\end{array}$ & Accession name & Source \\
\hline 1 & $\mathrm{DB} 1$ & Dolichos Diana & $\begin{array}{l}\text { Ashoka Seeds Private Limited, } \\
\text { Bangalore }\end{array}$ \\
\hline 2 & DB2 & Dolichos Nandini & $\begin{array}{l}\text { Prabhakar Seeds Private Limited, } \\
\text { Bangalore }\end{array}$ \\
\hline 3 & DB3 & PHS Dhoni & $\begin{array}{l}\text { Prabhakar Seeds Private Limited, } \\
\text { Bangalore }\end{array}$ \\
\hline 4 & DB4 & Rohini & Rasi Seeds Private Limited, Salem \\
\hline 5 & DB5 & Ankur Goldy & Ankur Seeds Private Limited, Nagpur \\
\hline 6 & DB6 & Konkan & $\begin{array}{l}\text { Dr. Balasheb Sawant Konkan Krishi } \\
\text { Vidyapeeth, Dapoli, Maharashtra }\end{array}$ \\
\hline 7 & DB7 & Dolichos Ruchi & $\begin{array}{l}\text { Indosun Agri Genetics Private } \\
\text { Limited, Hyderabad }\end{array}$ \\
\hline 8 & DB8 & Dolichos Nandi & $\begin{array}{l}\text { Aditya Seeds Private Limited, } \\
\text { Bangalore }\end{array}$ \\
\hline 9 & DB9 & Arka Jay & $\begin{array}{l}\text { Indian Institute of Horticultural } \\
\text { Research, Bangalore }\end{array}$ \\
\hline 10 & DB10 & Arka Vijay & $\begin{array}{l}\text { Indian Institute of Horticultural } \\
\text { Research, Bangalore }\end{array}$ \\
\hline 11 & DB11 & COGB -14 & $\begin{array}{l}\text { Tamil Nadu Agricultural University, } \\
\text { Coimbatore }\end{array}$ \\
\hline 12 & DB12 & Dolichos Senthil & $\begin{array}{l}\text { Senthil Seeds \& Company Private } \\
\text { Limited, Bangalore }\end{array}$ \\
\hline 13 & DB13 & PHS Dolichos & $\begin{array}{l}\text { Prabhakar Seeds Private Limited, } \\
\text { Bangalore }\end{array}$ \\
\hline 14 & DB14 & Kumbakonam local & Kumbakonam, Tamil Nadu \\
\hline 15 & DB15 & Madagadipet local & Pondicherry \\
\hline 16 & DB16 & Ottanchathiram local & Tamil Nadu \\
\hline 17 & DB17 & IC 354334 & $\begin{array}{l}\text { National Bureau of Plant Genetic } \\
\text { Resources, New Delhi. }\end{array}$ \\
\hline 18 & DB18 & IC 354336 & $\begin{array}{l}\text { National Bureau of Plant Genetic } \\
\text { Resources, New Delhi. }\end{array}$ \\
\hline 19 & DB19 & IC 354337 & $\begin{array}{l}\text { National Bureau of Plant Genetic } \\
\text { Resources, New Delhi. }\end{array}$ \\
\hline 20 & DB20 & Lakshmi & $\begin{array}{l}\text { Super Seeds Private Limited, } \\
\text { Hyderabad }\end{array}$ \\
\hline 21 & DB21 & Gold 24 & $\begin{array}{l}\text { Sun Star Seeds Private Limited, } \\
\text { Hyderabad }\end{array}$ \\
\hline 22 & DB22 & Dolli & Rasi Seeds Private Limited, Haryana \\
\hline 23 & DB23 & Theni local & Tamil Nadu \\
\hline
\end{tabular}


Table 2: Estimation of variability parameters for dolichos bean genotypes

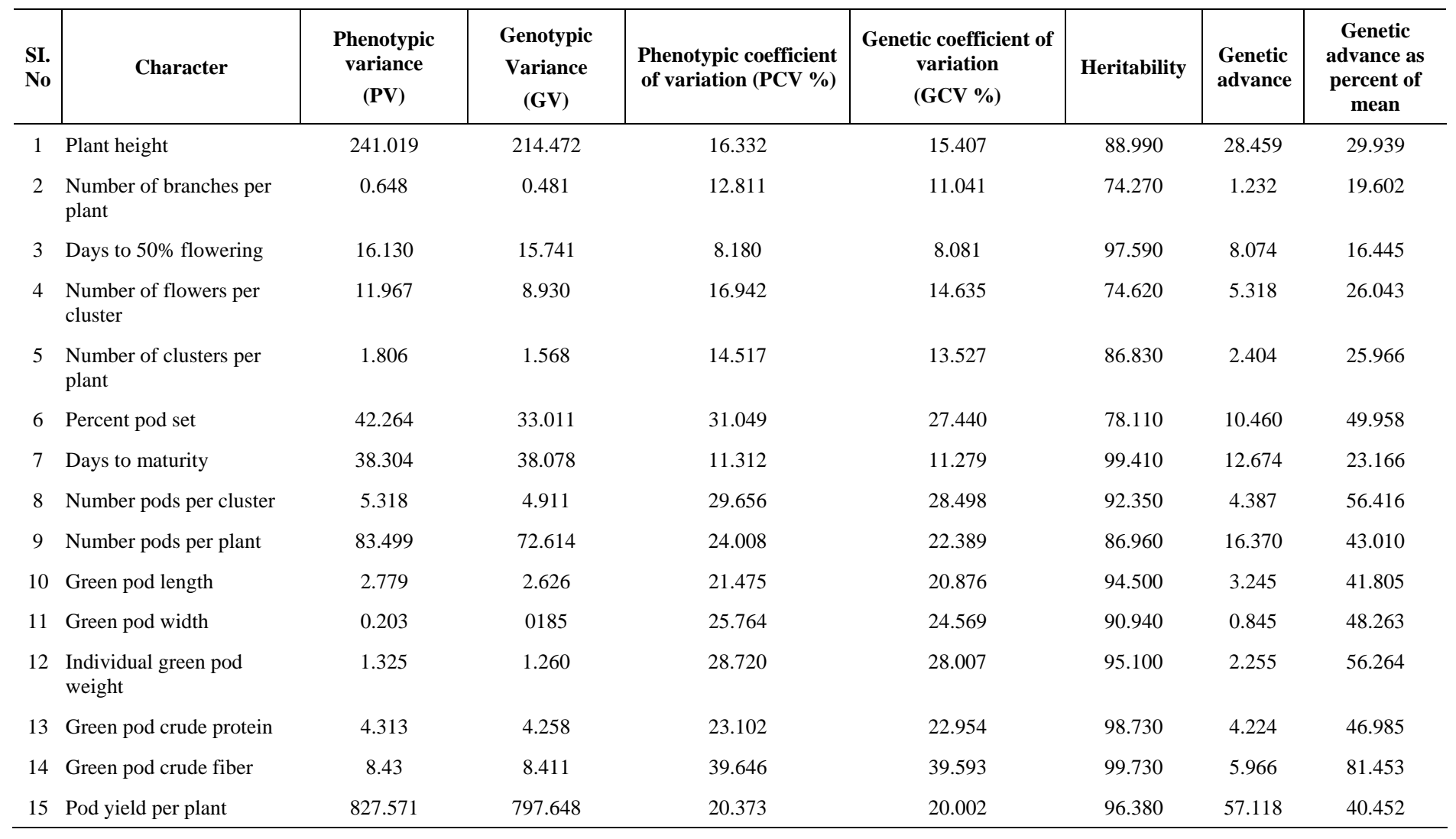


Variability in field bean

Table 3: Genotypic correlation coefficient for different characters of dolichos bean

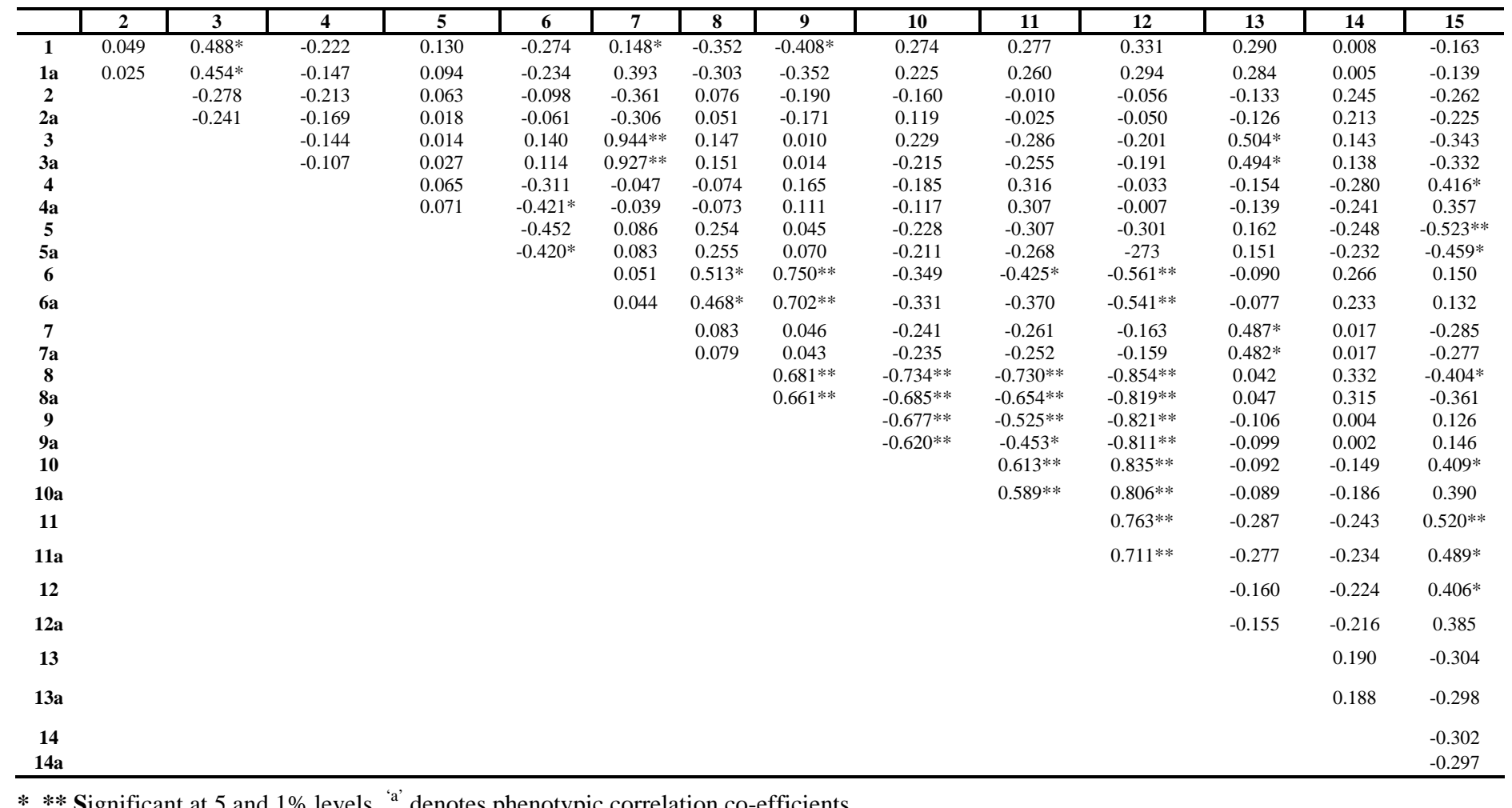

*** Significant at 5 and $1 \%$ levels. 'a' denotes phenotypic correlation co-efficients.

1 = Plant height, 2 = Number of branches per plant, $3=$ Days to 50\%age flowering, $4=$ Number of flowers per cluster, $5=$ Number of cluster per plant, $6=$ Percent pod set, $7=$ Days to maturity, $8=$ Number of pods per cluster, $9=$ Number of pods per plant, $10=$ Green pod length, 11 = Green pod width, 12 = Individual green pod weight, 13 = Green pod crude protein, 14 = Green pod crude fiber, $15=$ Pod yield per plant. 
Table 4. Path coefficient for direct and indirect effects of different traits

\begin{tabular}{|c|c|c|c|c|c|c|c|c|c|c|c|c|c|c|c|}
\hline & 1 & 2 & 3 & 4 & 5 & 6 & 7 & 8 & 9 & 10 & 11 & 12 & 13 & 14 & 15 \\
\hline 1 & -0.5017 & 0.0321 & 0.5871 & -0.2256 & 0.1479 & -0.4994 & -0.4426 & 0.0830 & -0.4582 & -0.2089 & -0.0671 & 1.2318 & 0.1579 & 0.0005 & -0.163 \\
\hline 2 & -0.0246 & 0.6547 & -0.3348 & -0.2164 & 0.0721 & -0.1789 & 0.3817 & -0.0180 & -0.2133 & -0.1220 & 0.0023 & -0.2090 & -0.0723 & 0.0163 & -0.262 \\
\hline 3 & -0.2448 & -0.1822 & 1.2030 & -0.1469 & 0.0161 & 0.2559 & -0.9996 & -0.0346 & 0.0116 & 0.1741 & 0.0693 & -0.7492 & 0.2747 & 0.0095 & -0.343 \\
\hline 5 & -0.0650 & 0.0414 & 0.0170 & 0.0661 & 1.1406 & -0.8250 & -0.0910 & -0.0600 & 0.0507 & 0.1739 & 0.0744 & -1.1180 & 0.0885 & -0.0165 & $-0.523 * *$ \\
\hline 6 & 0.1373 & -0.0642 & 0.1687 & -0.3164 & -0.5157 & 1.8245 & -0.0544 & -0.1210 & 0.8411 & 0.2656 & 0.1030 & -2.0870 & -0.0492 & 0.0177 & 0.150 \\
\hline 7 & -0.2098 & -0.2361 & 1.1362 & -0.0473 & 0.0981 & 0.0938 & -1.0584 & -0.0197 & 0.0511 & 0.1840 & 0.0631 & -0.6072 & 0.2656 & 0.0011 & -0.285 \\
\hline 10 & -0.1375 & 0.1048 & -0.2749 & -0.1885 & $0-0.2602$ & -0.6359 & 0.2556 & 0.1731 & -0.7598 & -0.7621 & -0.1485 & 3.1053 & -0.0499 & -0.0129 & $0.409 *$ \\
\hline 11 & -0.1389 & -0.0062 & -0.3442 & 0.3217 & -0.3505 & -0.7758 & 0.2759 & 0.1722 & -0.5887 & -0.4671 & -0.2422 & 2.8366 & -0.1564 & -0.0162 & $0.520^{* * *}$ \\
\hline 12 & -0.1661 & -0.0368 & -0.2423 & -0.0331 & -0.3428 & -1.0236 & 0.1728 & 0.2016 & -0.9209 & -0.6362 & -0.1847 & 3.7200 & -0.0873 & 0.0149 & $0.406 *$ \\
\hline 13 & -0.1453 & -0.0868 & 0.6060 & -0.1563 & 0.1852 & -0.1647 & -0.5156 & -0.0099 & -0.1190 & 0.0698 & 0.0695 & -0.5954 & 0.5453 & 0.0127 & -0.304 \\
\hline 14 & -0.0039 & 0.1602 & 0.1714 & -0.2850 & -0.2828 & 0.4854 & -0.0178 & -0.0783 & 0.0042 & 0.1476 & 0.0588 & -0.8323 & 0.1036 & 0.0666 & -0.302 \\
\hline
\end{tabular}

** Significant at $1 \%$ level * Significant at $5 \%$ level

1 = Plant height, 2 = Number of branches per plant, $3=$ Days to 50\%age flowering, $4=$ Number of flowers per cluster, $5=$ Number of cluster per plant, $6=$ Percent pod set, $7=$ Days to maturity, $8=$ Number of pods per cluster, $9=$ Number of pods per plant, $10=$ Green pod length, $11=$ Green pod width, 12 = Individual green pod weight, 13 = Green pod crude protein, 14 = Green pod crude fiber, 15 = Pod yield per plant. 